ИЗВЕСТИЯ АКАДЕМИИ НАУК ЭСТОНСКОИ ССР. ТОМ 30 Химия. 1981, № 4

\title{
ОПРЕДЕЛЕНИЕ МОЛИБДЕНА И ВАНАДИЯ АТОМНО-АБСОРБЦИОННЫМ МЕТОДОМ В АРГИЛЛИТАХ
}

Jelena HATSATURJAN, Reet TALKOP. MOLOBDEENI JA VANAADIUMI MAARAMINE POLEVKIVIDES AATOM-ABSORPTSIOONIMEETODIL

Elena KHACHATURYAN, Reet TALKOP. DETERMINATION OF MOLYBDENUM AND VANADIUM IN SHALES BY ATOMIC-ABSORPTION SPECTROPHOTOMETRY

\section{(Представил О. Эйзен)}

Настоящее сообщение посвящено вопросу экспрессного определения двух наиболее важных микрокомпонентов аргиллитов (молибдена и ванадия) атомно-абсорбционным методом без отделения сопутствующих элементов (железо, алюминий, титан и др.). Известные $\left[{ }^{1-4}\right]$ атомноабсорбционные методы определения молибдена и ванадия в основном разработаны в отношении объектов, уступающих по сложности аргиллитам. В большинстве случаев предусматривается экстракционное отделение основы или уравнивание калибровочных растворов и растворов проб по основным сопутствующим компонентам [5], что в отношении проб рассматриваемых объектов трудоемко и не всегда надежно. Между тем, величина атомной абсорбции для молибдена и ванадия в сильной степени зависит от суммарного присутствия других компонентов в объекте.

В связи с этим нами было изучено влияние некоторых физических (высота наблюдения, стехиометрический состав пламени) и химических (сопутствующие ионы, кислотность растворов, природа кислоты, буферные добавки) параметров на определение молибдена и ванадия. На основании проведенного исследо-

Калибровочные графики для определения молибдена и ванадия. 1 ванадий, 2 - молибден.

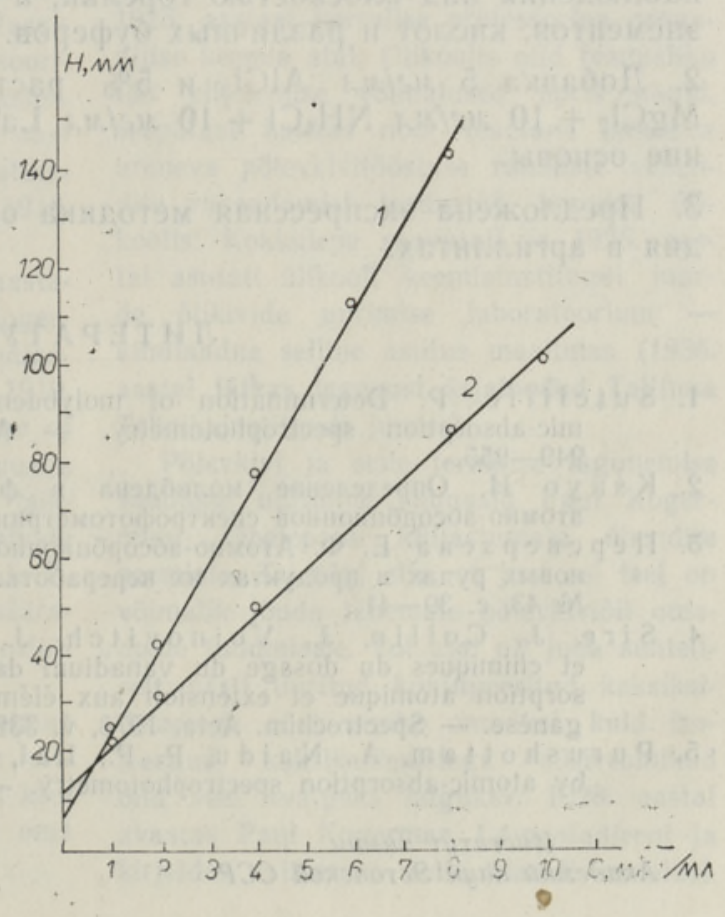


вания предложены условия прямого определения молибдена и ванадия из одного раствора без предварительного отделения сопутствующих компонентов. Ниже шриводится методика определения на приборе «Руе Unicam», модель 1900.

\section{Методика}

Навеску пробы $(0,5-1,0$ г) помещают в платиновую чашку и обжи-

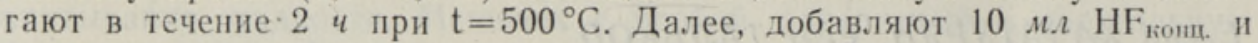
оставляют в таком виде на несколько часов. Затем добавляют 2 м. $\mathrm{H}_{2} \mathrm{SO}_{4}$ кон. и нагревают до белых паров. Путем трехкратной обработки водой удаляют $\mathrm{F}^{-}$. Соли растворяют в 15 мл $\mathrm{HCl}$ (1:1), фильтруют в колбу на $50 \mathrm{~m} \Omega$ и доводят объем до метки дистиллированной водой.

В аликвоту раствора добавляют 5 мг/мл $\mathrm{AlCl}_{3}$ н примерно $5 \%$

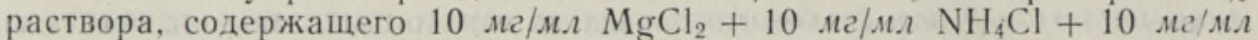
$\mathrm{LaCl}_{3}$ и проводят определение молибдена в воздушно-ацетиленовом пламени при следующих условиях: $\lambda=313,3$ нм, ширнна щели $=0,1 \mu$. $\mathrm{C}_{\text {возд. }}=4,5 \mathrm{~s} /$ мин, $\mathrm{C}_{\text {ацет, }}=1600 \mathrm{~cm}^{3} / \mathrm{suн,}, h_{\text {горелюп }}=6,0 \mathrm{\mu \mu}$.

Определение ванадия выполняется в пламени закись азота-ацетилен: $\lambda=318,3$ нм, ширина щели $=0,1$ м. $, \mathrm{C}_{\text {возд. }}=4,8 л /$ лин, $\quad \mathrm{C}_{\text {ацет. }}=$ $=4000 \mathrm{~cm}^{3} /$ мuн, $h_{\text {горелки }}=7,0 \mathrm{M \mu}$. Калибровочные растворы молибдена и ванадия, концентрацией $1-10$ мкг/мл, готовят ежедневно путем разбавления исходного раствора концентрацией 1 мг/мл бидистиллятом. Растворы пробы и растворы сравнения должны быть уравнены по кислотности. Предел обнаружения молибдена и ванадия соответственно $0,5 \mu \kappa z / \mu \Omega$ и $0,2 \mu \kappa z / \mu \Omega$.

\section{Выводы}

1. Изучено влияние стехиометрического состава пламени и высоты наблюдения над плоскостью горелки, а также влияние сопутствующих элементов, кислот и различных буферов.

2. Добавка $5 \mathrm{M} / \mu \Omega \mathrm{AlCl}_{3}$ и $5 \%$ раствора, содержащего $10 \mathrm{\mu \nu} / \mathrm{\mu} \Omega$ $\mathrm{MgCl}_{2}+10$ ме/мл $\mathrm{NH}_{4} \mathrm{Cl}+10 \mathrm{M} / \mathrm{M} \Omega \mathrm{LaCl}_{3}$ полностью устраняет влияние основы.

3. Предложена экспрессная методика определения молибдена и ванадия в аргиллитах.

\section{Л ИТ Е РА Т У РА}

1. Sutclifie, P. Determination of molybdenum in geological materials by atomic-absorption spectrophotometry. - Analyst, 1976, v. 101, N 1209, p. 949-955.

2. Кацуо И. Определение молибдена в флотационных концентратах методом атомно-абсорбционной спектрофотометрни. - РЖХ, 20Г $245,1978$.

3. Переверзев а Е. Ф. Атомно-абсорбционное определение молибдена в молибденовых рудах и продуктах их переработки. - Науч. тр. НИИ цвет. мет., 1977, № 43 , c. $39-41$.

4. Sire, J., Collin, J., Voinovitch, J. A. Etude des conditions physiques et chimiques du dosage du vanadium dans les aciers par spectrometrie d'absorption atomique et extension aux éléments: cuivre, chrome, nickel, et manganèse. - Spectrochim. Acta, 1978, v. 33B, N 1-2, p. 31-45.

5. Purushottam, A., Naidu, P. P., Lal, S. S. Determination of molybdenum by atomic-absorption spectrophotometry. - Talanta, 1972, v. 19, p. 1193-1198. 